\title{
Reduction in Water Stress for Tree Saplings Using Hydrogels in Soil
}

\author{
Maryam Kargar, Rahul Suresh, Matthew Legrand, Pierre Jutras, 0. Grant Clark, Shiv 0. Prasher \\ Macdonald Campus, McGill University, Ste-Anne-de-Bellevue, QC, Canada \\ Email: maryam.kargar@mcgill.ca
}

How to cite this paper: Kargar, M., Suresh, R., Legrand, M., Jutras, P., Clark, O.G. and Prasher, S.O. (2017) Reduction in Water Stress for Tree Saplings Using Hydrogels in Soil. Journal of Geoscience and Environment Protection, 5, 27-39.

http://dx.doi.org/10.4236/gep.2017.51002

Received: December 1, 2016

Accepted: January 2, 2017

Published: January 5, 2017

Copyright $\odot 2017$ by authors and Scientific Research Publishing Inc. This work is licensed under the Creative Commons Attribution International License (CC BY 4.0).

http://creativecommons.org/licenses/by/4.0/

\begin{abstract}
The effect of soil amendment with hydrogel on reducing water stress was tested for Siberian elm (Ulmus pumila) and silver maple (Acer saccharinum) saplings. The trees were planted in soils with one of two concentrations of hydrogel $(0.5 \%$ or $1 \%$ dry weight) as compared to the control soil ( $0 \%$ of hydrogel) and watered either daily, weekly, or bi-weekly. Growth was monitored by measuring height and stem diameter. Stress was monitored by measuring SPAD readings and normalized difference vegetation index (NDVI), as proxy measures of chlorophyll content and photosynthetic activity, respectively. Water stress decreased NDVI $(\mathrm{p}<0.05)$ but did not have a significant effect on SPAD readings. Soil with $0.5 \%$ concentration of hydrogel was positively associated with greater height and NDVI $(\mathrm{p}<0.01)$ for both maple and elm trees. Hydrogels had a species-specific effect on SPAD readings. The interaction between hydrogel concentration and the watering regime had a significant effect on the height and NDVI $(p<0.01)$ of elms, but not maples. The improved performance of water-stressed tree saplings in hydrogel-amended soils was presumably due to the ability of hydrogels to absorb and then gradually release water and nutrients. This is of special interest for urban foresters, because water stress and nutrient deficiency are two important growthlimiting factors for street trees.
\end{abstract}

\section{Keywords}

Tree Growth, Hydrogel, Photosynthesis, Super Absorbent Polymer, Water Stress

\section{Introduction}

The successful establishment and maintenance of urban trees are often seriously constrained by water stress. Urban trees are exposed to excess and deficit soil moisture, but drought is generally considered to be the more serious health 
threat. Impermeable surfaces and compacted soil diminish infiltration of precipitation into tree root zones [1]. Also, urban soils are warmer than soils in natural areas because of the surrounding pavement and lack of vegetation [2]. Lack of adequate precipitation infiltration and the high temperature of urban soil can result in drought stress which will limit plant growth and function through a series of morphological, physiological and metabolic changes [3]. Plants close their leaf stomata in response to moderate water stress [4], which decreases leaf transpiration [5]. Subsequently, the diffusion of $\mathrm{CO}_{2}$ from the atmosphere into carboxylation sites in leaves decreases and photosynthesis is impeded [6]. As the water stress worsens, photosynthetic activity decreases, mainly due to chloroplast dehydration and the consequent biochemical constraints [4]. Ionic, osmotic, or other effects of cellular water loss can inhibit biochemical processes in waterstressed plants [7].

Several studies demonstrated a decline in the chlorophyll content of plants under water stress [3] [4] [8], so chlorophyll content could be a useful indicator of drought stress. As a surrogate measure of the vegetation vigor and productivity of plants, normalized difference vegetation index (NDVI) is another estimator of plant response to water deficit [9]. This index is calculated from the red $\left(\mathrm{R}_{\mathrm{Red}}\right)$ and near-infrared $\left(\mathrm{R}_{\mathrm{NIR}}\right)$ reflectance from vegetation (Equation (1)).

$$
\mathrm{NDVI}=\left(\mathrm{R}_{\mathrm{NIR}}-\mathrm{R}_{\mathrm{Red}}\right) /\left(\mathrm{R}_{\mathrm{NIR}}+\mathrm{R}_{\mathrm{Red}}\right)
$$

The NDVI ranges from -1 to 1 , with 0 representing no vegetation. Negative values represent non-vegetative surfaces, while values approaching 1 represent very dense vegetation [10]. Aguilar et al. [11] found that annual changes in the NDVI of woody plants were associated with changes in precipitation and groundwater. They measured lower NDVI values $(0.65-0.70)$ in the dry years and found linear relationships between accumulated rainfall and maximum NDVI values as indicators of overall productivity of plants. Over a nine-year period (1989-1997), Wang et al. [12] also found a positive correlation between the NDVI and the soil moisture values in Kansas forestlands.

\subsection{Super Absorbent Polymers or Hydrogels}

There have been few studies of water saving technologies in urban environments, especially involving tree pits. A technology to potentially reduce the effect of drought stress, particularly on seedlings and saplings, could be the hydrophilic, cross-linked polymers known as super absorbent polymers or hydrogels. The term hydrogel is sometimes used for these compounds because when the dry crystals absorb water, they take on the consistency of a gel [13]. Hydrogels can retain up to 400 times their weight in water when saturated, but will not dissolve in water [14]. The hydrophilic functional groups attached to the polymeric backbone enable hydrogels to absorb water, while the cross-links between network chains make hydrogels resistant to dissolution [15]. Ideally, at least $95 \%$ of the water stored in hydrogels is available to plants [16].

Hydrogels can also retain nutrients when incorporated into the soil, making 
them available for plant growth whenever required. Hydrogels are hydrophilic and contain carboxylic groups, enabling them to bind cations and adsorb water [17]. The water and nutrients stored in hydrogels are released gradually for plant growth under water limiting conditions, whereas under non-water limiting conditions, they are reported to enhance nutrient uptake for plant growth [18]. This is of special interest for urban foresters, because water stress and nutrient deficiency are two important growth-limiting factors for street trees.

Different factors affect the absorptive capacity of hydrogels for water. These factors include the tolerance of hydrogels to ionic solutions, the tensions at which they bind water, and the speed with which they degrade in the field [19]. According to Orzolek [20], under field conditions, polymers will lose 10\% to $15 \%$ of their activity each year. The degradation of polymers can be due to microbial activity [21], chemical decomposition [20], or physical modification over time. In spite of the beneficial aspects of hydrogels in the soil and their effects on plant growth, an overabundance of hydrogels can have negative consequences in some cases [13]. For instance, Sarvaš et al. [22] observed high mortality (64\%) of pine seedlings caused by an overdose of hydrogel. Shooshtarian et al. [23] attributed a high seedling mortality rate in hydrogel-amended soil to a reduction of free air space resulting from the swelling of the hydrogel and the consequent reduction in soil aeration.

In general, the main function of hydrogel in soil is to preempt the negative effects of water deficiency on plant growth and productivity. However, its effectiveness varies depending on the situation. Accordingly, the objective of this research was to observe the effects of differential proportions of hydrogel, under conditions of different water availability, on the growth of Siberian elm and silver maple in greenhouse experiments.

\section{Materials and Methods}

\subsection{Growth Test}

The project was performed in a greenhouse located on the Macdonald Campus of McGill University, Sainte-Anne-de-Bellevue, Canada, under humid summer conditions of $28^{\circ} \mathrm{C}-30^{\circ} \mathrm{C}, 65 \%$ relative humidity, and a 16 -h photoperiod. The experiment was run in two phases of six weeks each: the first from Aug. $18^{\text {th }}$ to Sep. $30^{\text {th }}, 2014$, and the second from Oct. $2^{\text {nd }}$ to Nov. $11^{\text {th }}, 2014$. Siberian elm (Ulmus pumila) and silver maple (Acer saccharinum) saplings were potted in sieved soil (tamisé) (Laniel Prodamex, Pierrefonds, QC). The soil in each pot was thoroughly mixed with one of two proportions ( 0.5 and $1.0 \%$ dry weight) of dry Super ABA 200 (Iramont Inc., Laval, QC), a potassium polyacrylamide hydrogel, as compared to the control soil ( $0 \%$ of hydrogel). Water-soluble fertilizer (20-20-20, Passion Jardins, Vaudreuil-Dorion, QC) was added to the soil at the beginning of the experiment.

In the first phase of the experiment, the trees were arranged in a full-factorial, completely randomized design with twelve replicates, totaling 72 pots. The trees were irrigated regularly and the pots were randomly rearranged at each watering. 
At the end of this phase, 18 trees, i.e. three replicates per treatment, were sacrificed and analyzed for growth and physiological parameters.

The second phase used the remaining trees (Siberian elm and silver maple, potted in soil with one of three proportions of hydrogel), but also included three different irrigation schedules, replicated three times, totaling 54 trees. The trees were either watered daily (no stress), weekly (moderate stress), or every second week (severe stress). In order to keep the water availability similar within treatment levels, the same amount of water was added to each pot in that level at the time of watering.

\subsection{Growth and Physiological Measurements}

The measured growth parameters were total height from the soil surface to the top of the crown and trunk diameter at the soil surface, measured every second week. Normalized difference vegetation index (NDVI) was measured using a Crop Circle ${ }^{\mathrm{Tx}}$ ACS-430 active crop canopy sensor (Holland Scientific, Lincoln, NE). Leaves were tested using a SPAD 502 Plus Chlorophyll Meter (Spectrum Technologies, Aurora, IL). The SPAD-502 meter measures leaf transmittance in the red $(650 \mathrm{~nm})$ and infrared $(940 \mathrm{~nm})$ bands. The SPAD meter value, typically between 0.0 and 50.0, is proportional to the amount of chlorophyll in the leaf [24]. Both NDVI and SPAD readings were measured and recorded every second week.

\subsection{Statistical Analysis}

A Kolmogorov-Smirnov test showed that none of the data were normal, so a two-step transformation was used to rank the values by percentile, giving uniformly-distributed probabilities, and then map them onto normally-distributed $z$-scores using an inverse-normal function [25]. A general linear model was performed to diagnose the significant interactions between independent variables (hydrogel concentration, watering frequencies and the species). Analysis of Variance (ANOVA) was then applied to the transformed data to test for significant effects of tree species, hydrogel concentration, and watering frequency on the transformed values of growth, NDVI, and SPAD readings ( $\alpha=0.05)$ (SPSS Statistics v.21, IBM Corporation, Armonk, NY). Mean values of the measured variables for each hydrogel concentration were compared among watering frequencies using the Tukey method ( $\alpha=0.05$ ) [26]. A bivariate correlation test was also performed between the dependent variables (stem height, stem diameter, NDVI, and SPAD readings) and the independent variables (watering regime and hydrogel concentration).

\section{Results and Discussion}

\subsection{Patterns of Growth and Photosynthetic Activity under Different Watering Regimes}

Hydrogel had no observable effect on well-watered trees, as measured during the first phase of the experiment. This is consistent with previous studies [27]. The 
experimental factors did have significant effects on the water-stressed trees, as observed during the second phase of the experiment. Significant interactions were observed between tree species and hydrogel concentration, and between tree species and watering frequency (Table 1). This result indicates that the elms and maples each responded differently to the hydrogel treatment and watering frequency. Therefore, the rest of the statistical analysis was performed separately on the two tree species.

\subsection{Stem Height and Diameter}

According to Rais et al. [28], drought-induced water stress can influence tree growth even before it has an evident effect on physiological processes such as photosynthesis. We observed that change in stem height was a more sensitive indicator of drought stress than stem diameter in both species (Table 2), as have other authors [28]. Bouriaud et al. [29] surmised that tree height is sensitive to water stress because of restricted movement of water to the actively growing extremities. Moreover, water stressed trees might favor root extension over crown expansion in an attempt to compensate for the water deficit [28] [30].

We observed a negative effect of watering frequency on the height of silver maple $(\mathrm{r}=-0.29, \mathrm{p}<0.05)$. In corroboration with this result, Elhadi et al. [31] also found tree height increased more rapidly when saplings were watered every nine days than when they were watered every three or six days. They concluded that frequent irrigation is not always profitable for plant growth because it can negatively affect root respiration and growth. As a result, water and nutrient uptake by roots diminishes and tree growth declines [32].

Under water stress, $0.5 \%$ hydrogel concentration increased stem height in both tree species $(r=0.48, \mathrm{p}<0.05$, Figure 1 , Table 2 and Table 3 ). We also observed a significant interaction between hydrogel and watering frequency on

Table 1. Significance of interaction of species, SAP weight percentages, and watering frequency on growth and physiological parameters.

\begin{tabular}{ccccc}
\hline & Stem height & Stem diameter & NDVI & SPAD readings \\
\hline Species $\times$ SAP & $0.001^{\star *}$ & 0.810 & 0.949 & $0.000^{* * *}$ \\
Species $\times$ watering frequency & $0.012^{\star *}$ & $0.024^{\star}$ & 0.256 & 0.230 \\
\hline
\end{tabular}

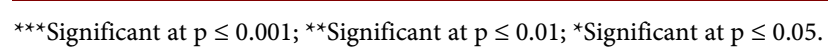

Table 2. The significance of SAP, watering frequency and between subject effects on stem height and diameter.

\begin{tabular}{ccccc}
\hline & \multicolumn{2}{c}{ Siberian elm } & \multicolumn{2}{c}{ Silver maple } \\
\cline { 2 - 4 } & Stem height & Stem diameter & Stem height & Stem diameter \\
\hline SAP & $0.000^{* * *}$ & 0.883 & $0.000^{* * *}$ & 0.778 \\
Watering frequency & $0.004^{* *}$ & 0.848 & $0.000^{* * *}$ & $0.001^{* *}$ \\
SAP $\times$ watering frequency & $0.000^{* * *}$ & 0.818 & $0.006^{* *}$ & 0.279 \\
\hline
\end{tabular}

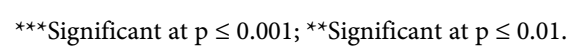




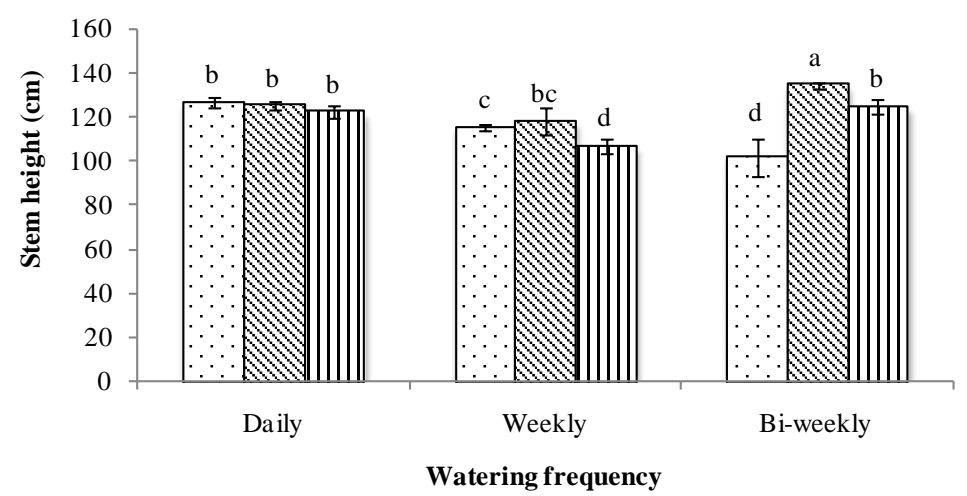

(a)

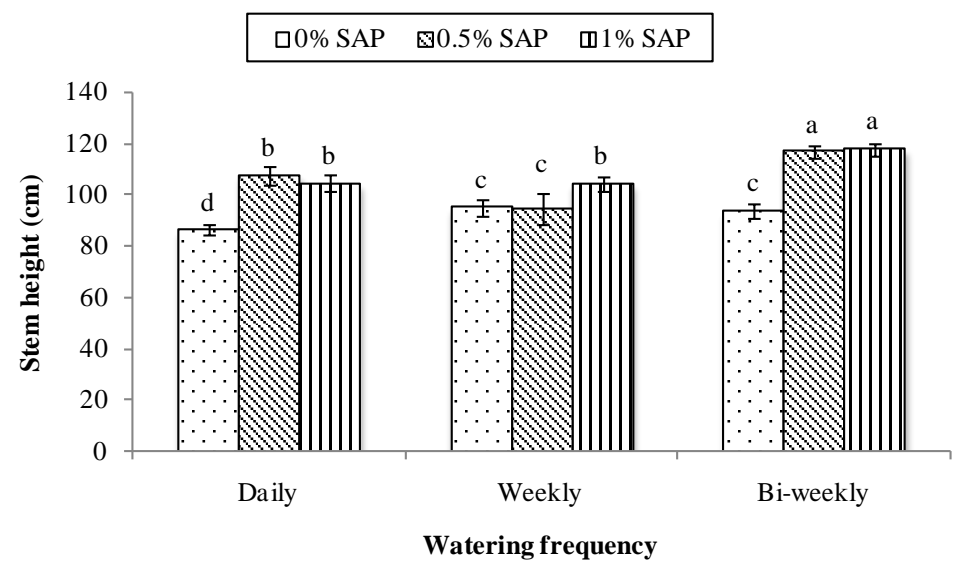

(b)

Figure 1. Comparison mean effect of SAP levels (wt\%) on stem height at different watering frequency for (a) Siberian elm and (b) silver maple. Values are the mean ( \pm standard error) of the replicates per treatment.

Table 3. Significance of mean difference of growth and physiological parameters for Siberian elm and silver maple based on SAP weight percentages.

\begin{tabular}{|c|c|c|c|c|c|c|c|}
\hline \multirow{2}{*}{ Parameter } & \multirow{2}{*}{ SAP (wt\%) } & \multicolumn{3}{|c|}{ Siberian elm } & \multicolumn{3}{|c|}{ Silver maple } \\
\hline & & 0 & 0.5 & 1 & 0 & 0.5 & 1 \\
\hline \multirow{3}{*}{ Stem height } & 0 & - & & & - & & \\
\hline & 0.5 & $0.016^{*}$ & - & & $0.000^{* * *}$ & - & \\
\hline & 1 & 0.972 & $0.008^{* *}$ & - & $0.000^{\star * *}$ & 0.894 & - \\
\hline \multirow{3}{*}{ Stem diameter } & 0 & - & & & - & & \\
\hline & 0.5 & 0.934 & - & & 0.861 & - & \\
\hline & 1 & 0.998 & 0.914 & - & 0.776 & 0.986 & - \\
\hline \multirow{3}{*}{ NDVI } & 0 & - & & & - & & \\
\hline & 0.5 & $0.004^{* *}$ & - & & $0.03^{*}$ & - & \\
\hline & 1 & $0.004^{\star \star}$ & 0.997 & - & $0.001^{\star * *}$ & 0.511 & - \\
\hline \multirow{3}{*}{$\begin{array}{c}\text { Chlorophyll } \\
\text { content }\end{array}$} & 0 & - & & & - & & \\
\hline & 0.5 & 0.221 & - & & 0.91 & - & \\
\hline & 1 & $0.001^{\star *}$ & $0.000^{* * *}$ & - & $0.000^{* * *}$ & $0.000^{* * *}$ & - \\
\hline
\end{tabular}

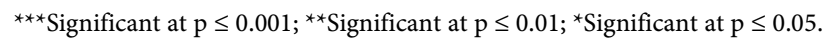


stem height, indicating that the effect of the hydrogel differed depending on the watering regime (Table 2). Various authors have attributed the positive effects of hydrogel on plant height and survival during drought conditions to improved root growth or to the retention of soil water near the newly planted seedling [27].

\subsection{Normalized Difference Vegetation Index (NDVI)}

Physiological processes in plants are highly constrained by water deficits [33], as illustrated by the positive correlation between NDVI and watering frequency both for Siberian elm $(r=0.37, p<0.01)$ and for silver maple $(r=0.16, p<0.05)$. Under drought stress, stomata tend to close, the rate of photosynthesis decreases, and respiration increases [34]. Hassan and Ali [35] and Silber et al. [36] suggested, however, that reduced photosynthesis during drought can be due to nutrient deficiency rather than lack of water. In either case, hydrogels can absorb either water or nutrients from the soil [37] and gradually release them to the soil in the root zone during drought conditions [38]. The absorption and rerelease of nutrients by the hydrogel can maintain photosynthetic rates [39]. This might explain the positive correlation of hydrogel with NDVI $(0.5 \%, r=0.25, \mathrm{p}<0.01)$ in both elms and maples (Figure 2 and Table 3 and Table 4), while the interaction between hydrogel and watering frequency did not have a significant effect on NDVI for the maples (Table 4).

\subsection{SPAD Readings}

The effect of watering frequency on SPAD readings (chlorophyll content) was not significant in this study. Other authors considered invariance of chlorophyll content and photosynthesis under stress as physiological resilience [40] [41].

Under drought stress, hydrogel concentration was negatively correlated with SPAD readings for elms (hydrogel $=1 \%, r=-0.37, \mathrm{p}<0.01$, Figure $3(\mathrm{a})$, Table 3). Others have also reported that hydrogel had a slightly negative or null effect on plant performance [42]. However, the concentration of hydrogel was positively correlated with SPAD readings (chlorophyll content) in the maples (hydrogel $=1 \%, r=0.62, p<0.01$, Figure $3(b))$. The different responses of the two tree species are consistent with their coping strategies in the face of water stress [18] [43]. In general, silver maples grow in wet, poorly drained soils as in floodplains or stream banks [44] [45]. They are tolerant of long periods of inundation and oxygen deficiency [46]. On the contrary, Siberian elms prefer well-drained soil [47]. As the concentration of hydrogel in the soil increases, free airspace and oxygen availability can be reduced when the hydrogel swells. Silver maples are well adapted to such conditions while Siberian elms are not.

\section{Conclusion}

The addition of hydrogel to the potting soil had a significant effect on the growth, photosynthesis, and chlorophyll concentration of Siberian elm and silver maple saplings under water stress. In water-stressed trees, $0.5 \%$ (dry weight) 


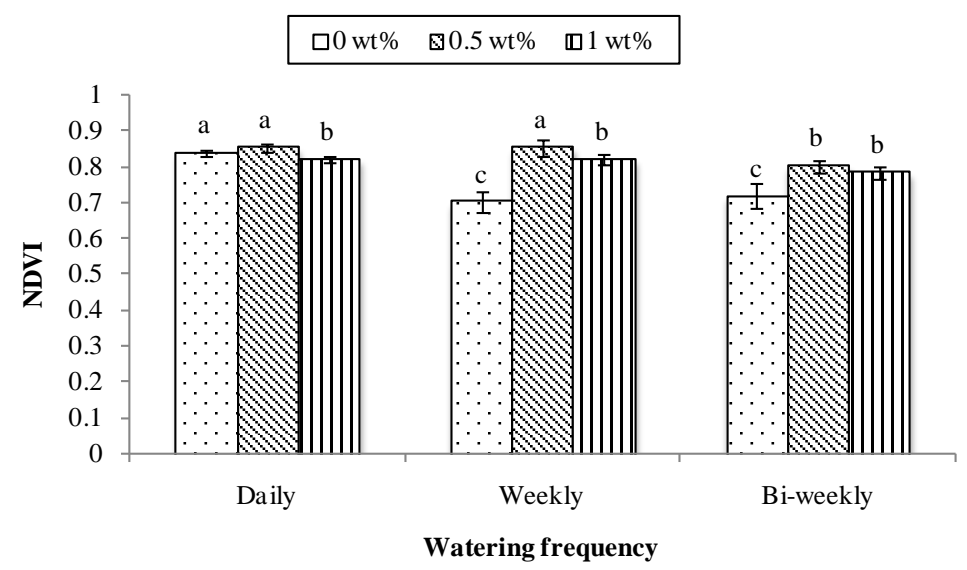

(a)

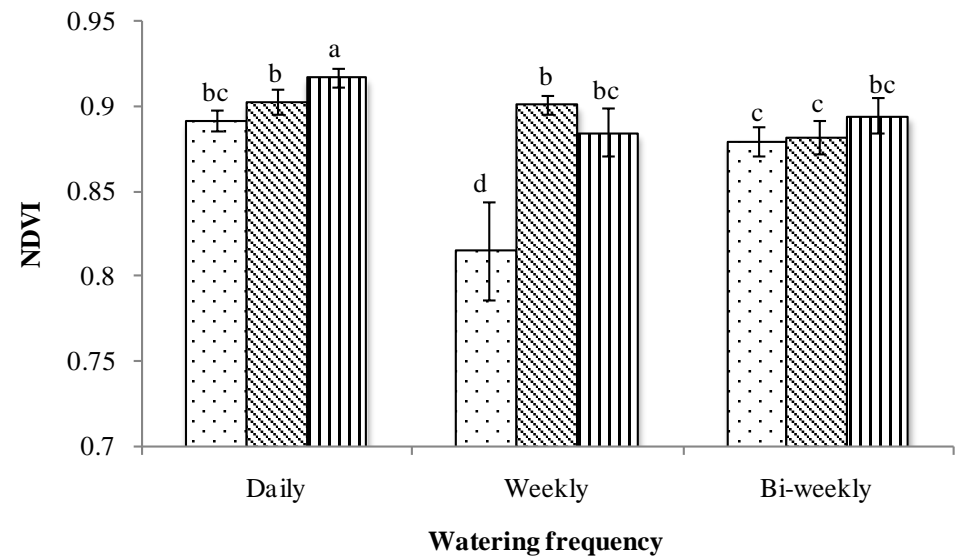

(b)

Figure 2. Comparison mean effect of SAP levels (wt \%) on NDVIs at different watering frequency for (a) Siberian elm and (b) silver maple. Values are the mean ( \pm standard error) of the replicates per treatment.

Table 4. Significance of SAP, watering frequency and their interaction effects on NDVI and SPAD readings.

\begin{tabular}{ccccc}
\hline & \multicolumn{2}{c}{ Siberian elm } & \multicolumn{2}{c}{ Silver maple } \\
\cline { 2 - 5 } & NDVI & SPAD readings & NDVI & SPAD readings \\
\hline SAP & $0.002^{* *}$ & $0.000^{* * *}$ & $0.001^{* *}$ & $0.000^{* * *}$ \\
Watering frequency & $0.000^{* * *}$ & 0.060 & $0.011^{*}$ & 0.420 \\
SAP $\times$ watering frequency & $0.001^{* * *}$ & 0.550 & 0.506 & 0.473 \\
\hline
\end{tabular}

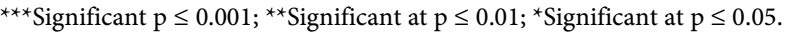

hydrogel increased growth in both tree species, as indicated by change in height, and also increase in NDVI (photosynthesis) $(\mathrm{p}<0.01)$. These effects were presumably due to the ability of hydrogel to absorb and rerelease nutrients and water. There was also a species-specific relationship between the concentration of hydrogel in the soil and the SPAD readings (chlorophyll content) of Siberian elms and silver maples. The specificity of this effect might be attributed to differences in the adaptation of the tree species to water stress. Since Siberian elm 


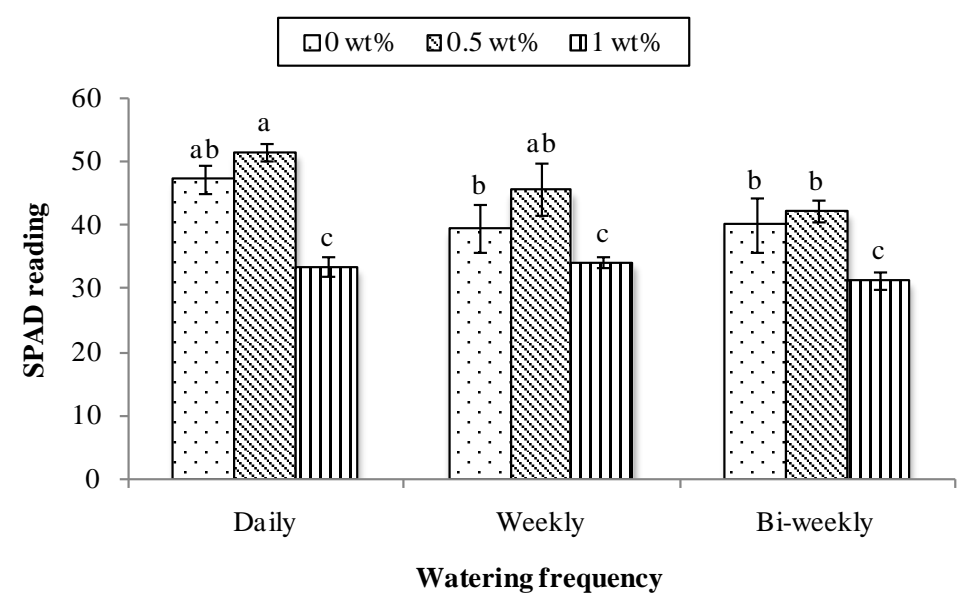

(a)

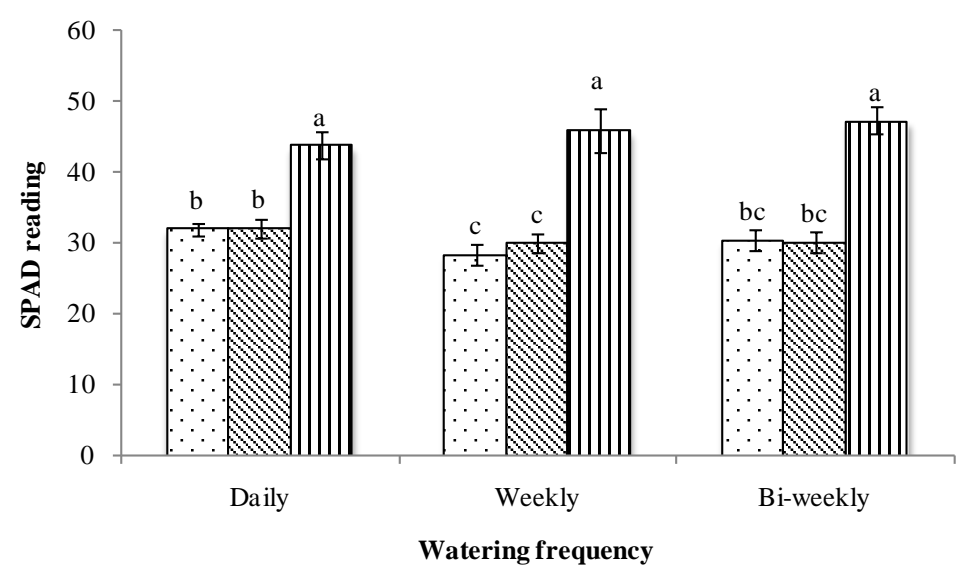

(b)

Figure 3. Comparison mean effect of SAP levels on SPAD readings at different watering frequency for (a) Siberian elm and (b) silver maple. Values are the mean ( \pm standard error) of the replicates per treatment.

and silver maple are popular urban tree species in temperate climates, it is recommended that they be evaluated in field trials using hydrogel-amended soils, as a possible countermeasure to the water stress, which is associated with urbanization and climate change. A relatively high proportion of impermeable surfaces in urban environment and change in the intensity and frequency of rainfall due to the climate variability result in water stress for street trees and increase the need for improving the capability of urban soil to deal with water stress and buffer its effect for street trees with soil amendments such as hydrogel.

\section{Acknowledgements}

This project was financially supported by NSERC Discovery Grant program. The authors also thank Mr. Guy Rimmer for providing the greenhouse services available for the research team.

\section{References}

[1] Zwack, J.A., Graves, W.R. and Townsend, A.M. (1998) Leaf Water Relations and 
Plant Development of Three Freeman Maple Cultivars Subjected to Drought. Journal of the American Society of Horticultural Science, 122, 371-375.

[2] Watson, G.W., et al. (2014) The Management of Tree Root Systems in Urban and Suburban Settings: A Review of Soil Influence on Root Growth. Arboriculture and Urban Forestry, 40, 193-217.

[3] Hayatu, M. and Mukhtar, F.B. (2010) Physiological Responses of Some Drought Resistant Cowpea Genotypes (Vigna unguiculata (L.) Walp) to Water Stress. Bayero Journal of Pure and Applied Sciences, 3, 69-75.

[4] Poormohammad Kiani, S., et al. (2008) QTL Analysis of Chlorophyll Fluorescence Parameters in Sunflower (Helianthus annuus L.) under Well-Watered and WaterStressed Conditions. Plant Science, 175, 565-573. https://doi.org/10.1016/j.plantsci.2008.06.002

[5] Krishna Surendar, K., et al. (2013) Effect of Water Stress on Leaf Temperature, Transpiration Rate, Stomatal Diffusive Resistance and Yield of Banana. Plant Gene and Trait, 4, 43-47. https://doi.org/10.5376/pgt.2013.04.0008

[6] Jamnická, G., et al. (2013) The Soil Hydrogel Improved Photosynthetic Performance of Beech Seedlings Treated under Drought. Plant, Soil, and Environment, 59, 446451.

[7] Lawlor, D.W. (1995) Effects of Water Deficit on Photosynthesis. In: Smirnoff, M., Ed., Environment and Plant Metabolism: Flexibility and Acclimation, Bios Scientific Publishers, 129-160.

[8] Zhang, M., et al. (2007) Uniconazole-Induced Tolerance of Soybean to Water Deficit Stress in Relation to Changes in Photosynthesis, Hormones and Antioxidant System. Journal of Plant Physiology, 164, 709-717. https://doi.org/10.1016/j.jplph.2006.04.008

[9] Groeneveld, D.P. and Baugh, W.M. (2007) Correcting Satellite Data to Detect Vegetation Signal for Eco-Hydrologic Analyses. Journal of Hydrology, 344, 135-145. https://doi.org/10.1016/j.jhydrol.2007.07.001

[10] Pietragalla, J. and Vega, A.M. (2012) Normalized Difference Vegetation Index. In: Pask, A., Pietragalla, J., Mullan, D. and Reynolds, M., Eds., Physiological Breeding II: A Field Guide to Wheat Phenotyping, International Maize and Wheat Improvement Center (CIMMYT), 37-41.

[11] Aguilar, C., Zinnert, J.C., Polo, M.J. and Young, D.R. (2012) NDVI as an Indicator for Changes in Water Availability to Woody Vegetation. Ecological Indicators, 23, 290-300. https://doi.org/10.1016/j.ecolind.2012.04.008

[12] Wang, J., Rich, P.M. and Price, K.P. (2003) Temporal Responses of NDVI to Precipitation and Temperature in the Central Great Plains. USA International Journal of Remote Sensing, 24, 2345-2364. https://doi.org/10.1080/01431160210154812

[13] Chirino, E., Vilagrosa, A. and Ramón Vallejo, V. (2011) Using Hydrogel and Clay to Improve the Water Status of Seedlings for Dryland Restoration. Plant and Soil, 344, 99-110. https://doi.org/10.1007/s11104-011-0730-1

[14] Savi, T., Marin, M., Boldrin, D., Incerti, G., Andri, S. and Nardini, A. (2014) Green Roofs for a Drier World: Effects of Hydrogel Amendment on Substrate and Plant Water Status. Science of the Total Environment, 490, 467-476. https://doi.org/10.1016/j.scitotenv.2014.05.020

[15] Ahmed, E.M. (2015) Hydrogel: Preparation, Characterization, and Applications: A Review. Journal of Advanced Research, 6, 105-121. https://doi.org/10.1016/j.jare.2013.07.006

[16] Nazarli, H. and Zardashti, M.R. (2010) The Effect of Drought Stress and Super Ab- 
sorbent Polymer (A200) on Agronomical Traits of Sunflower (Helianthus annuus L.) under Field Condition. Cercetări Agronomice în Moldova, 43, 5-14.

[17] Hütterman, A., Orikiriza, L.J.B. and Agaba, H. (2009) Application of Superabsorbent Polymers for Improving the Ecological Chemistry of Degraded or Polluted Lands. Clean-Soil, Air, Water, 37, 517-526. https://doi.org/10.1002/clen.200900048

[18] Orikiriza, L.J.B., Agaba, H., Eilu, G., Kabasa, J.D., Worbes, M. and Hüttermann, A. (2013) Effects of Hydrogels on Tree Seedling Performance in Temperate Soils before and after Water Stress. Journal of Environmental Protection, 4, 713-721. https://doi.org/10.4236/jep.2013.47082

[19] Callaghan, T.V., Lindley, D.K., Ali, O.M., Nour, H.A.E. and Bacon, P.J. (1989) The Effect of Water-Absorbing Synthetic Polymers on the Stomatal Conductance, Growth and Survival of Transplanted Eucalyptus microtheca Seedlings in the Sudan. Journal of Applied Ecology, 26, 663-672. https://doi.org/10.2307/2404090

[20] Orzolek, M.D. (1993) Use of Hydrophilic Polymers in Horticulture. HortTechnology, 3, 41-44.

[21] Stahl, J.D., Cameron, M.D., Haselbach, J. and Aust, S.D. (2000) Biodegradation of Superabsorbent Polymers in Soil. Environmental Science and Pollution Research, 7, 83-88. https://doi.org/10.1065/espr199912.014

[22] Sarvaš, M., Pavlenda, P. and Takáčová, E. (2007) Effect of Hydrogel Application on Survival and Growth of Pine Seedlings in Reclamations. Journal of Forest Science, 53, 204-209.

[23] Shooshtarian, S., Abedi-Kupai, J. and TehraniFar, A. (2011) Evaluation of Application of Superabsorbent Polymers in Green Space of Arid and Semi-Arid Regions with Emphasis on Iran. Journal of Biodiversity and Ecological Sciences, 1, 258-269.

[24] Ling, Q., Huang, W. and Jarvis, P. (2011) Use of a SPAD-502 Meter to Measure Leaf Chlorophyll Concentration in Arabidopsis thaliana. Photosynthesis Research, 107, 209-214. https://doi.org/10.1007/s11120-010-9606-0

[25] Templeton, G.F. (2011) A Two-Step Approach for Transforming Continuous Variables to Normal: Implications and Recommendations for IS Research. Communications of the Association for Information Systems, 28, 41-58.

[26] Tukey, J.W. (1949) Comparing Individual Means in the Analysis of Variance. Biometrics, 5, 99-114. https://doi.org/10.2307/3001913

[27] Arbona, V., Iglesias, D.J., Jacas, J., Primo-Millo, E., Talon, M. and Gómez-Cadenas, A. (2005) Hydrogel Substrate Amendment Alleviates Drought Effects on Young Citrus Plants. Plant and Soil, 270, 73-82. https://doi.org/10.1007/s11104-004-1160-0

[28] Rais, A., van de Kuilen, J.-W.G. and Pretzsch, H. (2014) Growth Reaction Patterns of Tree Height, Diameter, and Volume of Douglas-Fir (Pseudotsuga menziesii [Mirb.] Franco) under Acute Drought Stress in Southern Germany. European Journal of Forest Research, 133, 1043-1056. https://doi.org/10.1007/s10342-014-0821-7

[29] Bouriaud, O., Leban, J.-M., Bert, D. and Deleuze, C. (2005) Intra-Annual Variations in Climate Influence Growth and Wood Density of Norway Spruce. Tree Physiolo$g y$, 25, 651-660. https://doi.org/10.1093/treephys/25.6.651

[30] Pretzsch, H., Dieler, J., Matyssek, R. and Wipfler, P. (2010) Tree and Stand Growth of Mature Norway Spruce and European Beech under Long-Term Ozone Fumigation. Environmental Pollution, 158, 1061-1070. https://doi.org/10.1016/j.envpol.2009.07.035

[31] Elhadi, M.A., Ibrahim, K.A. and Abdel Magid, T.D. (2013) Effect of Different Watering Regimes on Growth Performance of Five Tropical Trees in the Nursery. 
JONARES, 1, 14-18.

[32] Kramer, P.J. (1987) The Role of Water Stress in Tree Growth. Journal of Arboriculture, 13, 33-38.

[33] Vicente-Serrano, S.M., et al. (2013) Response of Vegetation to Drought Time-Scales across Global Land Biomes. Proceedings of the National Academy of Sciences, 110, 52-57. https://doi.org/10.1073/pnas. 1207068110

[34] Agaba, H., Orikiriza, L.J.B., Esegu, J.F.O., Obua, J., Kabasa, J.D. and Hüttermann, A. (2010) Effects of Hydrogel Amendment to Different Soils on Plant Available Water and Survival of Trees under Drought Conditions. Clean-Soil, Air, Water, 38, 328-335.

[35] Hassan, F.A.S. and Ali, E.F. (2014) Impact of Different Water Regimes Based on Class-A Pan on Growth, Yield and Oil Content of Coriandrum sativum L. Plant. Journal of the Saudi Society of Agricultural Sciences, 13, 155-161. https://doi.org/10.1016/j.jssas.2013.05.001

[36] Silber, A., Xu, G. and Wallach, R. (2003) High Irrigation Frequency: The Effect on Plant Growth and on Uptake of Water and Nutrients. Acta Horticulture, 627, 89-96. https://doi.org/10.17660/ActaHortic.2003.627.10

[37] Sita, R.C.M., Reissmann, C.B., Marques, R., de Oliveira, E. and Taffarel, A.D. (2005) Effect of Polymers Associated with N and K Fertilizer Sources on Dendrathema grandiflorum Growth and $\mathrm{K}, \mathrm{Ca}$ and Mg Relations. Brazilian Archives of Biology and Technology, 48, 335-342.

[38] Pattanaaik, S.K., Singh, B., Wangchu, L., Debnath, P., Hazarika, B.N. and Pandey, A.K. (2015) Effect of Hydrogel on Water and Nutrient Management of Citrus Limon. International Journal of Agriculture Innovation and Research, 3, 2319-1473.

[39] Khodadadi Dehkordi, D., Kashkuli, H.A., Naderi, A. and Shamsnia, S.A. (2013) Evaluation of Deficit Irrigation and Superabsorbent Hydrogel on Some Growth Factors of SCKaroun701 Corn in the Climate of Khuzestan. Advances in Environmental Biology, 7, 527-534.

[40] Pugnaire, F.I., Serrano, L. and Pardos, J. (1999), Constraints by Water Stress on Plant Growth, In: Pessarakli, M., Ed., Handbook of Plant and Crop Stress, Marcel Dekker, Inc., New York, 271-285.

[41] Tongo, A., Mahdavi, A. and Sayad, E. (2014) Effect of Superabsorbent Polymer Aquasorb on Chlorophyll, Antioxidant Enzymes and Some Growth Characteristics of Acacia victoriae Seedlings under Drought Stress. Ecopersia, 2, 571-583.

[42] Del Campo, A.D., Hermoso, J., Flors, J., Lidón, A. and Navarro-Cerrillo, R.M. (2011) Nursery Location and Potassium Enrichment in Aleppo Pine Stock 2. Performance under Real and Hydrogel-Mediated Drought Conditions. An International Journal of Forest Research, 84, 235-245.

[43] Clemente, A.S., et al. (2004) Restoration of a Limestone Quarry: Effect of Soil Amendments on the Establishment of Native Mediterranean Sclerophyllous Shrubs. Restoration Ecology, 12, 20-28. https://doi.org/10.1111/j.1061-2971.2004.00256.x

[44] Saeki, I., Christopher, W.B., Burton, V. and Murakami, N. (2011) Comparative Phylogeography of Red Maple (Acer rubrum L.) and Silver Maple (Acer saccharinum L.): Impacts of Habitat Specialization, Hybridization and Glacial History. Journal of Biogeography, 38, 992-1005. https://doi.org/10.1111/j.1365-2699.2010.02462.x

[45] Barnes, B.V., Saeki, I. and Kitazawa, A. (2004) Occurrence and Landscape Ecology of a Rare Disjunct Maple Species, Acer pycnanthum, and Comparison with Acer rubrum. Environmental Reviews, 12, 163-196. https://doi.org/10.1139/a04-007 
[46] Koda, H. (1999) Silver Maple: A Victim of Its Own Adaptability. Arnoldia, 59, 23-31.

[47] United States Department of Agriculture and Natural Resources Conservation Service and USDA NRCS National Plant Data (2003) Plant Fact Sheet: Siberian elm. 2.

Submit or recommend next manuscript to SCIRP and we will provide best service for you:

Accepting pre-submission inquiries through Email, Facebook, LinkedIn, Twitter, etc. A wide selection of journals (inclusive of 9 subjects, more than 200 journals)

Providing 24-hour high-quality service

User-friendly online submission system

Fair and swift peer-review system

Efficient typesetting and proofreading procedure

Display of the result of downloads and visits, as well as the number of cited articles Maximum dissemination of your research work

Submit your manuscript at: http://papersubmission.scirp.org/

Or contact gep@scirp.org 